\title{
Bioconversion of High Concentrations of Hydrogen Sulfide to Elemental Sulfur in Airlift Bioreactor
}

\author{
Mohamed Abdel-Monaem Zytoon, ${ }^{1,2}$ Abdulraheem Ahmad AlZahrani, ${ }^{3}$ \\ Madbuli Hamed Noweir, ${ }^{4}$ and Fadia Ahmed El-Marakby ${ }^{2}$ \\ ${ }^{1}$ Department of Industrial Engineering, King Abdulaziz University, P.O. Box 80204, Jeddah 21589, Saudi Arabia \\ ${ }^{2}$ Department of Occupational Health and Air Pollution, High Institute of Public Health, Alexandria University, \\ 165 El Horreya Avenue, Alexandria, Egypt \\ ${ }^{3}$ Department of Chemical and Material Engineering, King Abdulaziz University, P.O. Box 80204, Jeddah 21589, Saudi Arabia \\ ${ }^{4}$ Center of Excellence for Environmental Studies, King Abdulaziz University, P.O. Box 80204, Jeddah 21589, Saudi Arabia
}

Correspondence should be addressed to Mohamed Abdel-Monaem Zytoon; mzytoon@kau.edu.sa

Received 7 May 2014; Revised 4 July 2014; Accepted 4 July 2014; Published 22 July 2014

Academic Editor: Anli Geng

Copyright (C) 2014 Mohamed Abdel-Monaem Zytoon et al. This is an open access article distributed under the Creative Commons Attribution License, which permits unrestricted use, distribution, and reproduction in any medium, provided the original work is properly cited.

\begin{abstract}
Several bioreactor systems are used for biological treatment of hydrogen sulfide. Among these, airlift bioreactors are promising for the bioconversion of hydrogen sulfide into elemental sulfur. The performance of airlift bioreactors is not adequately understood, particularly when directly fed with hydrogen sulfide gas. The objective of this paper is to investigate the performance of an airlift bioreactor fed with high concentrations of $\mathrm{H}_{2} \mathrm{~S}$ with special emphasis on the effect of $\mathrm{pH}$ in combination with other factors such as $\mathrm{H}_{2} \mathrm{~S}$ loading rate, oxygen availability, and sulfide accumulation. $\mathrm{H}_{2} \mathrm{~S}$ inlet concentrations between 1,008 ppm and 31,215 ppm were applied and elimination capacities up to $113 \mathrm{~g} \mathrm{H}_{2} \mathrm{~S} \mathrm{~m}^{-3} \mathrm{~h}^{-1}$ were achieved in the airlift bioreactor under investigation at a $\mathrm{pH}$ range 6.5-8.5. Acidic $\mathrm{pH}$ values reduced the elimination capacity. Elemental sulfur recovery up to $95 \%$ was achieved under oxygen limited conditions ( $\mathrm{DO}<0.2 \mathrm{mg} / \mathrm{L}$ ) and at higher $\mathrm{pH}$ values. The sulfur oxidizing bacteria in the bioreactor tolerated accumulated dissolved sulfide concentrations $>500 \mathrm{mg} / \mathrm{L}$ at $\mathrm{pH}$ values $8.0-8.5$, and near $100 \%$ removal efficiency was achieved. Overall, the resident microorganisms in the studied airlift bioreactor favored $\mathrm{pH}$ values in the alkaline range. The bioreactor performance in terms of elimination capacity and sulfur recovery was better at $\mathrm{pH}$ range 8-8.5.
\end{abstract}

\section{Introduction}

Hydrogen sulfide is emitted from many industrial activities. The toxicity, malodor, and corrosiveness of $\mathrm{H}_{2} \mathrm{~S}$ necessitate its removal from waste gas streams. The classical physicochemical processes for $\mathrm{H}_{2} \mathrm{~S}$ control have many drawbacks, such as large energy requirements, high capital and operating costs, and production of secondary wastes [1-7]. On the other hand, biological processes for the removal of $\mathrm{H}_{2} \mathrm{~S}$ are more attractive because they are believed to be inexpensive and cause no environmental pollution [5].

Biofilters packed with compost and other natural media [8-12] and those with synthetic beds [2, 3, 5, 6, 13-19] have been studied. However, these types of biofilters are limited to air streams with low concentrations of $\mathrm{H}_{2} \mathrm{~S}$. In addition, they produce waste streams containing sulfate/sulfuric acid, which need further treatment.

Several trials have been conducted to convert $\mathrm{H}_{2} \mathrm{~S}$ biologically into elemental sulfur $\left(S^{\circ}\right)$ that can be easily separated from the waste stream and further treated for marketing. In some of these, heterotrophic sulfide oxidizing bacteria (SOB) were used [20]. However, the cost of continuous organic carbon supply is one drawback of such process. Also, ironbased biological processes have been studied [21-24]. The process consisted of two reactors, which increased the capital and operating costs of the process.

Biotrickling filters with synthetic packing materials were studied for bioconversion of $\mathrm{H}_{2} \mathrm{~S}$ to $\mathrm{S}^{\mathrm{o}}$ using autotrophic 


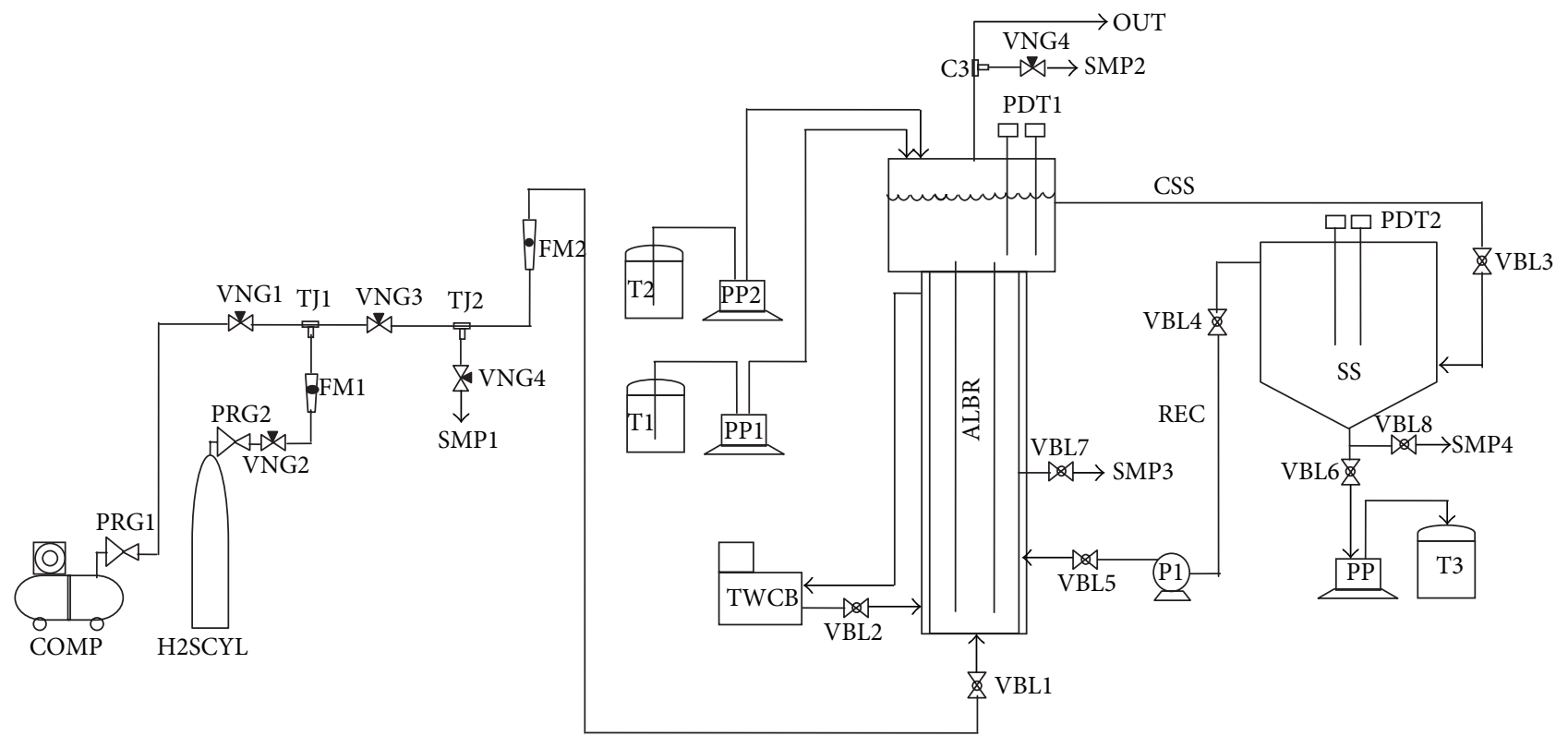

FIGURE 1: Schematic of the bioreactor system. ALBR: air-lift bioreactor; COMP: air compressor; CSS: cell and sulfur suspension; FM: flow meter; $\mathrm{H}_{2} \mathrm{SCYL}: \mathrm{H}_{2} \mathrm{~S}$ cylinder; OUT: outlet air to hood; P: circulation pump; PDT: $\mathrm{pH} / \mathrm{DO} /$ Temp sensors; PP: peristaltic pump; PRG: pressure reducer and pressure gauge; REC: recycled cell suspension; SMP: gas/liquid sampling; SS: sulfur settler; T: tanks (1: nutrient; 2: HCl; and 3: sulfur sludge); TJ: tee joint; TWCB: thermostated water circulation bath; VNG: gas needle valve; and VBL: liquid ball valve.

SOB [1, 25-27]. However, the problem with these types of reactors is that the produced sulfur particles block pores of the packing material and increase back pressure in the bioreactor. Therefore, they may not be suitable for treatment of gas streams with high $\mathrm{H}_{2} \mathrm{~S}$ concentrations or loads where large amount of elemental sulfur is expected to be produced, such as in case of air streams with high $\mathrm{H}_{2} \mathrm{~S}$ concentrations (up to several hundred or few thousands ppm) and energyrich gases such as biogas from anaerobic digesters or landfills which may contain $\mathrm{H}_{2} \mathrm{~S}$ concentrations up to several thousand ppm.

Suspended-growth bioreactors have no packing materials. When seeded with autotrophic SOB, they can overcome the aforementioned drawbacks. Study of the application of these bioreactors for biological oxidation of sulfide to elemental sulfur has been reported [28-32]. In these studies the inlet streams were sulfide-containing solutions rather than $\mathrm{H}_{2} \mathrm{~S}$ gas.

The objective of the current study was to study biological treatment of high concentrations of $\mathrm{H}_{2} \mathrm{~S}$ in an airlift bioreactor where direct injection of $\mathrm{H}_{2} \mathrm{~S}$ gas into the bioreactor is applied, with special emphasis on the effect of $\mathrm{pH}$ in combination with other factors such as sulfide loading rate, oxygen availability, and sulfide accumulation.

\section{Materials and Methods}

2.1. Experimental Set-Up. The experimental set-up shown in Figure 1 consisted of three main sections: the $\mathrm{H}_{2} \mathrm{~S}$-air preparation section, the airlift bioreactor, and the sulfur settler. The airlift bioreactor consisted of two concentric
$140 \mathrm{~cm}$ long acrylic tubes: the draft tube and the downcomer tube. The inside diameters of the two tubes were $6 \mathrm{~cm}$ and $15 \mathrm{~cm}$, respectively. The working volume was 24.75 liters. The phase separator was $30 \mathrm{~cm}$ long with $30 \mathrm{~cm}$ inside diameter and filled up to $50 \%$ of its height. The bioreactor was jacketed with a $20 \mathrm{~cm}$ inside diameter acrylic tube for temperature control inside the bioreactor. Several ports for inlet and outlet gas streams, nutrient supply, $\mathrm{pH}$ adjustment solutions, cell suspension circulation between the bioreactor and the settler, and $\mathrm{pH} / \mathrm{DO} /$ temperature sensors existed.

The sulfur settler was constructed from an acrylic tube with $40 \mathrm{~cm}$ height and $40 \mathrm{~cm}$ inside diameter, fitted to a conical bottom with $20 \mathrm{~cm}$ height. The bioreactor solution was continuously withdrawn to the settler for separation of the formed sulfur and the supernatant from the settler was recycled to the bioreactor. The settled sulfur slurry was withdrawn from the bottom of the settler cone for further treatment.

Air was driven to the bioreactor by a compressor. Before entering the bioreactor bottom, air was mixed with a stream of $\mathrm{H}_{2} \mathrm{~S}$ coming from a cylinder at a controlled flow rate to bring about a calculated $\mathrm{H}_{2} \mathrm{~S}$ concentration. Gas flow meters (Cole-Parmer EW-3227-08/28) were used to control air and $\mathrm{H}_{2} \mathrm{~S}$ flow rates and, consequently, $\mathrm{H}_{2} \mathrm{~S}$ concentrations.

2.2. Microbial Culture and Operation of the Bioreactor. The bioreactor was inoculated with $0.5 \mathrm{~kg}$ of activated sludge from Bani Malik Sewage Treatment Plant. A mixed culture of SOB was enriched using a thiosulfate nutrient solution for increasing biomass yield. The composition of the medium (in $\mathrm{g} / \mathrm{L}$ ) inside the bioreactor was as follows [4]: $\mathrm{Na}_{2} \mathrm{HPO}_{4} \cdot 7 \mathrm{H}_{2} \mathrm{O}$ : 
2.27; $\mathrm{KH}_{2} \mathrm{PO}_{4}: 1.8 ; \mathrm{MgCl}_{2} \cdot 7 \mathrm{H}_{2} \mathrm{O}: 0.1 ;\left(\mathrm{NH}_{4}\right)_{2} \mathrm{SO}_{4}: 1.98$; $\mathrm{MnCl}_{2} \cdot \mathrm{H}_{2} \mathrm{O}: 0.023 ; \mathrm{CaCl}_{2}: 0.03 ; \mathrm{FeCl}_{3} \cdot 6 \mathrm{H}_{2} \mathrm{O}: 0.033 ; \mathrm{Na}_{2} \mathrm{CO}_{3}$ : 1.0; and $\mathrm{Na}_{2} \mathrm{~S}_{2} \mathrm{O}_{3} \cdot 5 \mathrm{H}_{2} \mathrm{O}: 15.69$. Air was continuously supplied at a flow rate of $1.0 \mathrm{~L} / \mathrm{min}$ without circulation of the bioreactor solution for 3 days, after which circulation of the resulting suspension was initiated between the airlift bioreactor and the settler with continuous addition of the thiosulfate mineral solution $(5 \mathrm{~mL} / \mathrm{min})$ and withdrawal of the settled solids. Additional thiosulfate was added to the bioreactor on daily basis to insure sufficient supply for the developed SOB. When thiosulfate consumption rate by the developed SOB reached a maximum value, loading of $\mathrm{H}_{2} \mathrm{~S}$ gas to the bioreactor started and the nutrient medium without thiosulfate was supplied.

During a period of 176 days of operation, the airlift bioreactor was fed with $\mathrm{H}_{2} \mathrm{~S}$ as the sole sulfide source in predetermined concentrations (from 1,008 ppm to $31,215 \mathrm{ppm}$ ) in a continuous air stream of $1.0 \mathrm{liter} / \mathrm{min}$. The inlet concentration of $\mathrm{H}_{2} \mathrm{~S}$ was increased gradually to increase the sulfide loading rate (from 4.2 up to $132.4 \mathrm{~g} \mathrm{H}_{2} \mathrm{~S} \mathrm{~m}^{-3} \mathrm{~h}^{-1}$ ). The increase of $\mathrm{H}_{2} \mathrm{~S}$ inlet concentration was on the expense of oxygen concentration, resulting in a decrease in dissolved oxygen. During a period of almost stable load and dissolved oxygen, the value of $\mathrm{pH}$ was changed. The $\mathrm{pH}$ value was controlled by adding $\mathrm{HCl}$ or $\mathrm{Na}_{2} \mathrm{CO}_{3}$. The temperature of the bioreactor was controlled at $30^{\circ} \mathrm{C}$ most of the time.

2.3. Abiotic Experiment. The abiotic experiments were conducted by adding sterilized activated sludge to the nutrient solution in the bioreactor and $\mathrm{H}_{2} \mathrm{~S}$-air mixture (about $1000 \mathrm{ppm}$ ) was introduced to the bioreactor for three days. During the first few hours of the first day the removal efficiency was high and then sharply decreased to a maximum of $3 \%$ during the remaining period. Analysis of the bioreactor solution revealed accumulation of the sulfide in the bioreactor solution without formation of elemental sulfur. Only very slight increase in sulfate $(1.3 \%)$ and thiosulfate $(0.82 \%)$ over their original concentrations was observed.

2.4. Chemical Analysis. Sulfur species (sulfate, thiosulfate, sulfide, and elemental sulfur) were measured in the outlet liquid solution on a daily basis. Barium sulfate turbidimetric method [33] was used to measure sulfate concentration using a calibrated sulfate photometer (HANNA HI93751). Sulfide, thiosulfate, and polysulfide concentrations were measured by argentimetric potentiometric titration [34] using an automatic titrator (848 Titrino Plus, Metrohm). Silver nitrate was used as the titrant. The titrator was equipped with a calibrated silver/silver sulfide ion selective electrode for sulfide determination and a calibrated iodide electrode with $\mathrm{Ag} / \mathrm{AgCl}$ reference electrode for thiosulfate determination.

Measurement of $\mathrm{pH}$, dissolved oxygen (DO), and temperature inside the bioreactor and the settler was carried out using Orion 4-Star meter (Thermo Scientific) equipped with a calibrated ROSS Ultra $\mathrm{pH}$ electrode and a calibrated polarographic dissolved oxygen probe. Measurement of $\mathrm{pH}$ and temperature outside the bioreactor was carried out with a calibrated Handylab $1 \mathrm{pH}$ meter (Schott) and a Fisher Scientific digital thermometer, respectively.

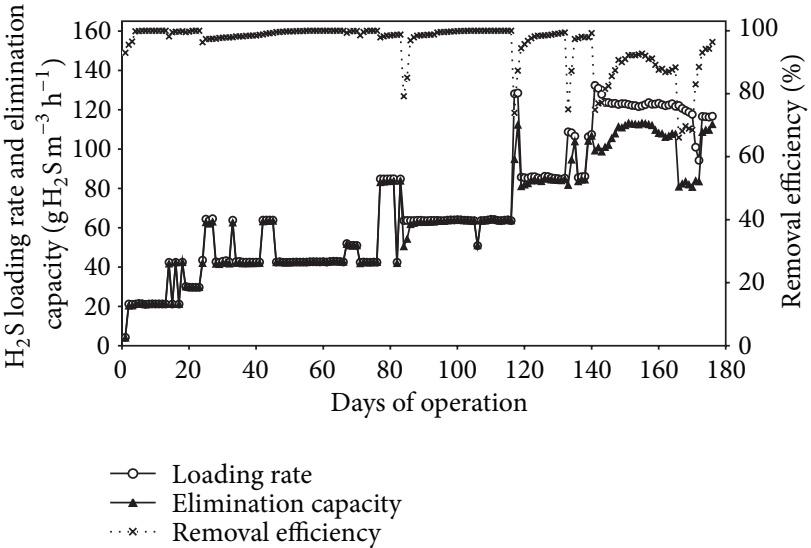

FIGURE 2: Daily performance of the airlift bioreactor over the study period.

$\mathrm{H}_{2} \mathrm{~S}$ inlet and outlet gas concentrations were monitored by a $\mathrm{H}_{2} \mathrm{~S}$ gas detector (BW GasAlertMax XT) with a measuring range of $0-200 \mathrm{ppm}$. Dilution of the gas in a dualvalve Tedlar PVF bag (Cole-Parmer EW-01409-93) with subsequent measurement was conducted when necessary.

\section{Results and Discussion}

3.1. Bioreactor Performance at Various $\mathrm{H}_{2} \mathrm{~S}$ Loading Rates and $p H$. The $\mathrm{H}_{2} \mathrm{~S}$ loading rate (LR), elimination capacity (EC), and removal efficiency (RE) of the bioreactor were calculated using the following equations:

$$
\begin{gathered}
\mathrm{LR}=\frac{C_{g i} \times Q_{g}}{V_{R}}, \\
\mathrm{EC}=\frac{\left[\left(C_{g i}-C_{g o}\right) \times Q_{g}-C_{l o} \times Q_{l o}\right]}{V_{R}}, \\
\mathrm{RE}=\frac{\left[\left(C_{g i}-C_{g o}\right) \times 100\right]}{C_{g i}},
\end{gathered}
$$

where $C_{g i}$ and $C_{g o}$ are the inlet and outlet gaseous sulfide concentrations $\left(\mathrm{g} / \mathrm{m}^{3}\right), C_{l o}$ is the liquid discharge sulfide concentration $\left(\mathrm{g} / \mathrm{m}^{3}\right), Q_{g}$ is the volumetric gas flow rate $\left(\mathrm{m}^{3} / \mathrm{h}\right), Q_{l o}$ is the volumetric bioreactor liquid discharge flow rate $\left(\mathrm{m}^{3} / \mathrm{h}\right)$, and $V_{R}$ is the working volume of the bioreactor $\left(\mathrm{m}^{3}\right)$.

Figure 2 shows $\mathrm{H}_{2} \mathrm{~S}$ loading rates and elimination capacities as well as the removal efficiency during a 176-day period of continuous operation. Hydrogen sulfide loading rate was increased gradually up to $132.4 \mathrm{~g} \mathrm{H}_{2} \mathrm{~S} \mathrm{~m}^{-3} \mathrm{~h}^{-1}$ at day 141 and then decreased down to about $116 \mathrm{~g} \mathrm{H}_{2} \mathrm{~S} \mathrm{~m}^{-3} \mathrm{~h}^{-1}$ during the remaining period. Elimination capacities up to about $113 \mathrm{~g} \mathrm{H}_{2} \mathrm{~S} \mathrm{~m}^{-3} \mathrm{~h}^{-1}$ were attained during the study period. In terms of $\mathrm{H}_{2} \mathrm{~S}$ gas removal efficiency, higher than $99 \%$ could be achieved at loading rates up to $108 \mathrm{~g} \mathrm{H}_{2} \mathrm{~S} \mathrm{~m}^{-3} \mathrm{~h}^{-1}$.

The effect of $\mathrm{pH}$ on the elimination capacity of the bioreactor at steady-state condition is illustrated in Figure 3. In all 


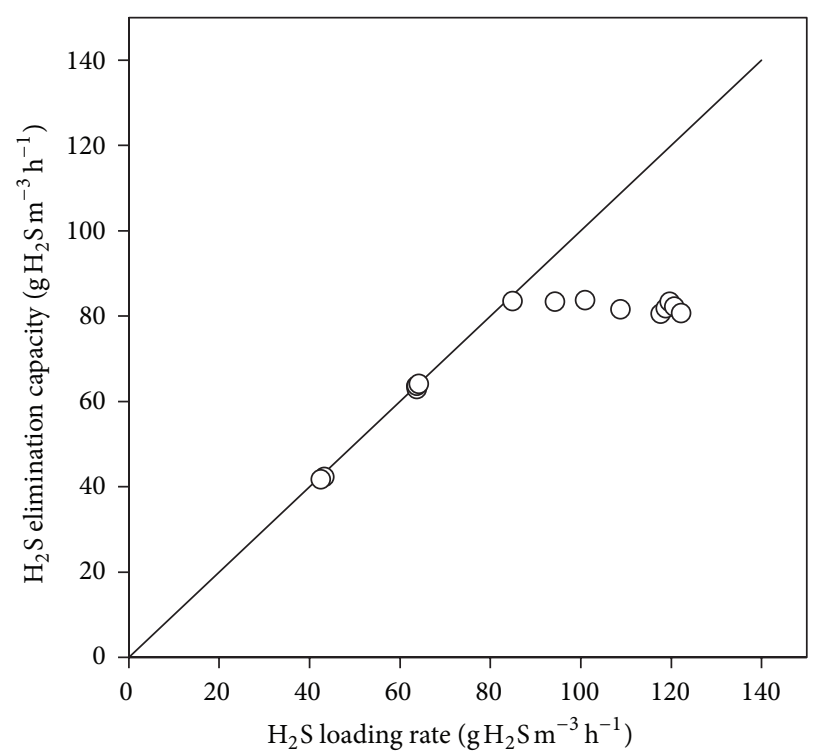

(a)

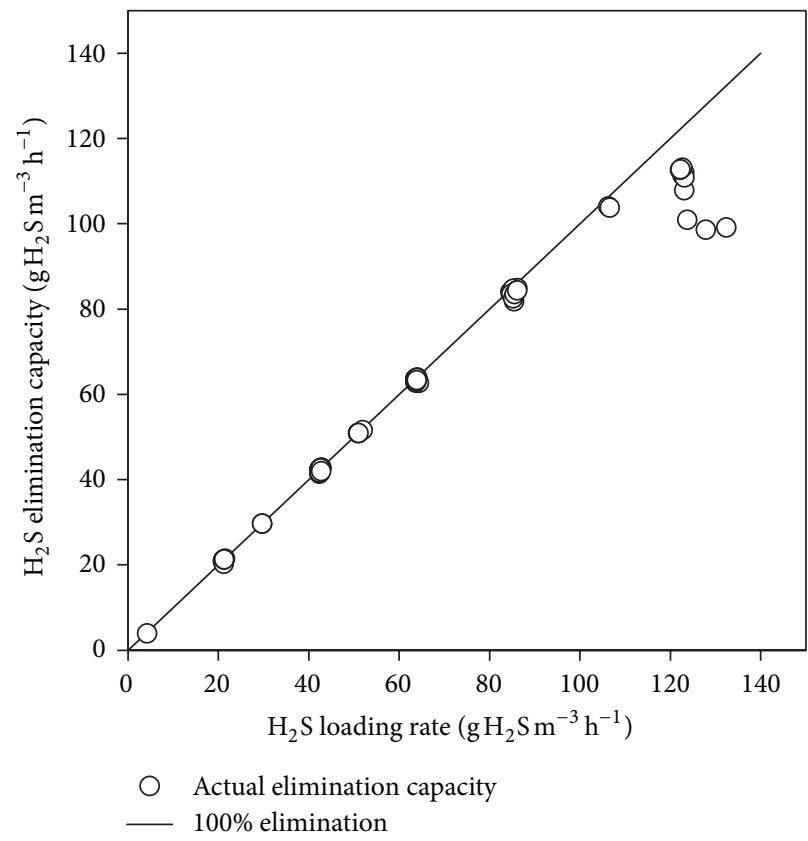

(c)

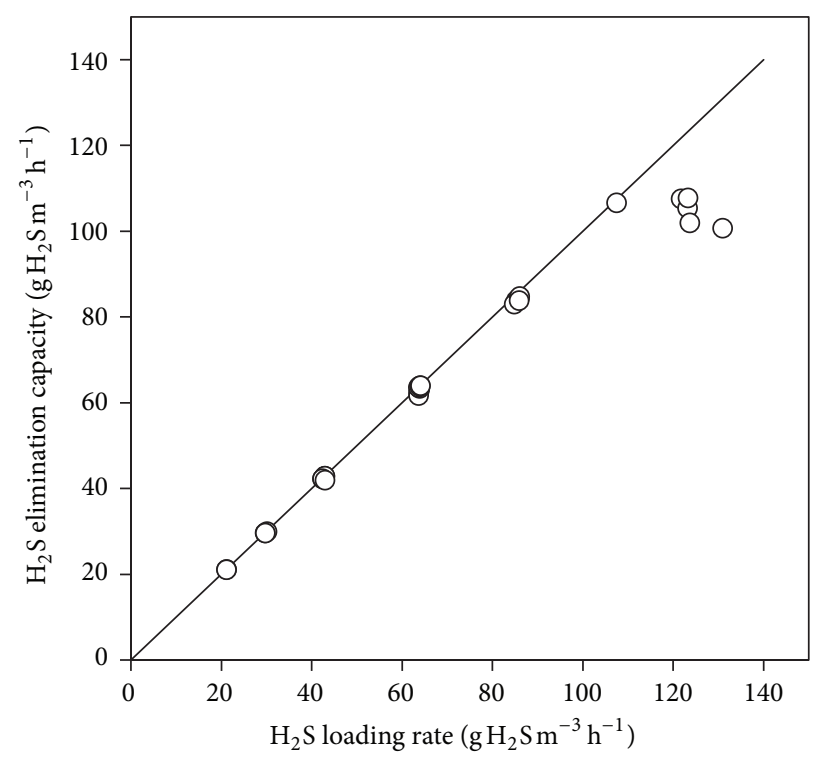

(b)

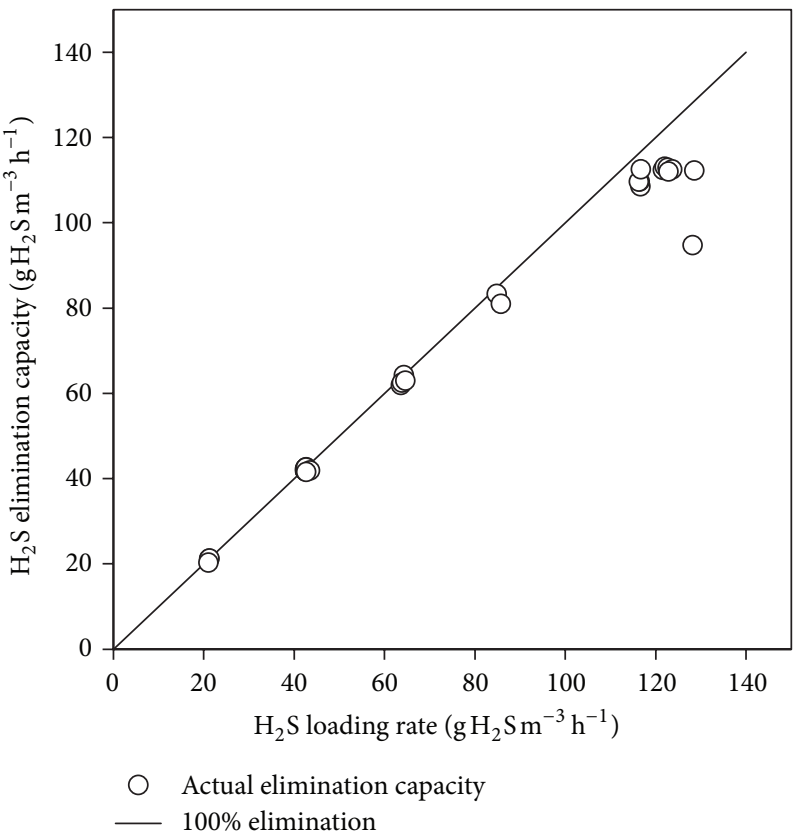

(d)

FIGURE 3: Effect of $\mathrm{pH}$ on the maximum elimination capacity of the airlift bioreactor: (a) $\mathrm{pH}=6.5-6.9$; (b) $\mathrm{pH}=7.0-7.4$; (c) $\mathrm{pH}=7.5-7.9$; and (d) $\mathrm{pH}=8.0-8.5$.

cases the elimination capacity of the bioreactor increased as the loading rate increased up to a maximum value beyond which a decrease in elimination capacity was observed. The maximum elimination capacities achieved at the studied $\mathrm{pH}$ ranges were about $84,108,113$, and $113 \mathrm{~g} \mathrm{H}_{2} \mathrm{~S} \mathrm{~m}^{-3} \mathrm{~h}^{-1}$ at $\mathrm{pH}$ ranges 6.5-6.9, 7.0-7.4, 7.5-7.9, and 8.0-8.5, respectively. These maximum elimination capacities were achieved at loading rates in the range $120-130 \mathrm{~g} \mathrm{H}_{2} \mathrm{~S} \mathrm{~m}^{-3} \mathrm{~h}^{-1}$.

Fernández et al. [26] found similar trend with $\mathrm{pH}$. However, their biotrickling filter was sensitive to $\mathrm{H}_{2} \mathrm{~S}$ overloads at $\mathrm{pH}$ higher than 7.5, which was not the case with the current
SOB. The close results at various $\mathrm{pH}$ ranges, particularly at $\mathrm{pH}$ $>7$, suggest that the SOB used in the bioreactor was capable of sustaining a wide $\mathrm{pH}$ range. This might be explained by the fact that the used SOB originated from a mixed culture rather than being a pure culture. The mixed culture contained several species of SOB allowing for adaptation to various environmental conditions.

The relatively low performance of the $\mathrm{SOB}$ at the lower $\mathrm{pH}$ range (below 7.0) might be attributed to biological capacity and/or mass-transfer limitation. $\mathrm{H}_{2} \mathrm{~S}$ is an acidic gas that dissolves in alkaline solutions with a rate higher than that 


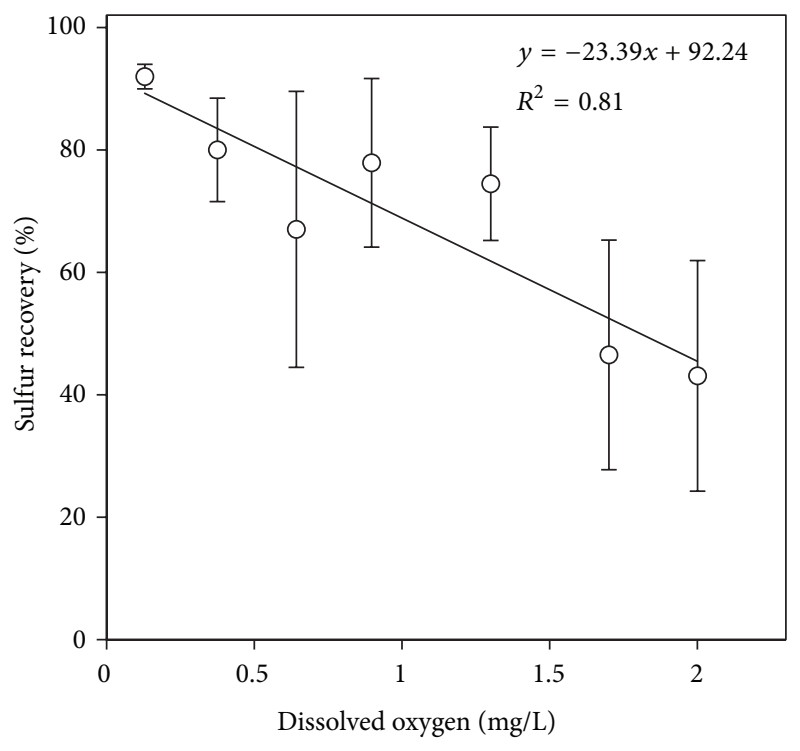

(a)

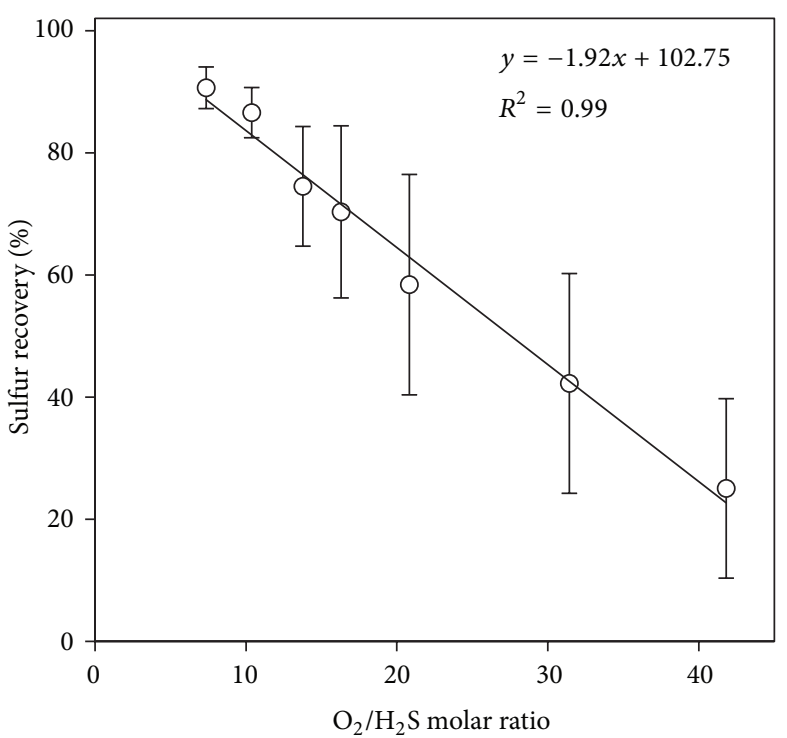

(b)

FIgURE 4: Effect of oxygen availability as (a) DO and (b) $\mathrm{O}_{2} / \mathrm{H}_{2} \mathrm{~S}$ molar ratio on sulfur recovery.

in acidic ones. Therefore, $\mathrm{pH}$ values in the alkaline range allow more $\mathrm{H}_{2} \mathrm{~S}$ to dissolve and consequently be available for the existing SOB. On the other hand, low $\mathrm{pH}$ values might affect the SOB performance due to existence of higher concentrations of free or unionized sulfide in the solution as will be discussed later in Section 3.4.

The maximum elimination capacity achieved in the current airlift bioreactor was higher than other bioreactor configurations $[2,3,5,6]$ and comparable to others $[25,27]$ (Table 1). However, it was lower than other airlift bioreactors where sulfide solution rather than $\mathrm{H}_{2} \mathrm{~S}$ gas was used as a feed $[29,35]$. One reason for that may be the absence of masstransfer problems in the liquid sulfide-fed airlift reactors compared to the gas-fed ones. This implies that application of $\mathrm{H}_{2} \mathrm{~S}$ gas-fed airlift bioreactors might require reactor volumes larger than those in the sulfide-fed ones. However, gas-fed bioreactors eliminate the use of additional absorption column to convert $\mathrm{H}_{2} \mathrm{~S}$ gas to sulfide solution and, thus, save the associated capital and operating costs. Also, the elimination capacity of the current bioreactor was lower than that of a biotrickling filter with polyurethane foam (PUF) packing [26] because of the higher mass-transfer rate provided by the large specific surface area of PUF. However, the disadvantage of this type of packing is pore clogging by the formed sulfur particles, which might raise maintenance problems.

\subsection{The Effect of Oxygen Availability on Bioconversion End} Product. The effect of oxygen availability as DO in the bioreactor solution is presented in Figure 4(a) which shows that elemental sulfur is the dominant end product at low DO. For instance, higher than $90 \%$ sulfur recovery (i.e., conversion of $\mathrm{H}_{2} \mathrm{~S}$ into elemental sulfur) could be achieved at DO lower than $0.3 \mathrm{mg} / \mathrm{L}$. As the DO concentration was increased sulfate formation increased on the expense of sulfur recovery. Sulfur recovery was lower than $40 \%$ at DO concentrations higher than $2 \mathrm{mg} / \mathrm{L}$. Similar results were found by Lohwacharin and Annachhatre [29].

Buisman et al. [28] reported that biological oxidation of sulfide to sulfate proceeds in two stages as follows:

$$
\begin{aligned}
& \mathrm{HS}^{-} \stackrel{[\mathrm{O}]+\mathrm{SOB}}{\longrightarrow} \text { membrane bound }\left[\mathrm{S}^{\circ}\right] \longleftrightarrow \mathrm{S}^{\mathrm{O}} \\
& \text { membrane bound }\left[\mathrm{S}^{\mathrm{O}}\right] \stackrel{[3 \mathrm{O}]}{\longrightarrow} \mathrm{SO}_{3}{ }^{-2} \stackrel{[\mathrm{O}]}{\longrightarrow} \mathrm{SO}_{4}{ }^{-2}
\end{aligned}
$$

In the first stage, which proceeds faster than the second stage, sulfide looses two electrons and membrane-bound polymeric sulfur compounds are being formed (2). In the second step, this sulfur is oxidized to sulfite and then to sulfate (3). The higher oxidized forms are formed only if the amount of available oxygen is sufficient. If oxygen extent is controlled for achieving the first stage only, elemental sulfur will be the end product of the process.

Sulfate is not preferred as end product because of its adverse effect on sewerage system and may constitute a secondary pollutant. On the other hand, elemental sulfur $\left(S^{\circ}\right)$ is a noncorrosive solid that is easy to handle and transport. In addition, it has a commercial value exceeding that of sulfuric acid (or sulfate) [36]. Therefore, direction of bioconversion of $\mathrm{H}_{2} \mathrm{~S}$ towards elemental sulfur formation is preferred.

It was reported in many published work that bioconversion of the inlet sulfide can be limited to elemental sulfur by maintaining DO concentration at $<0.1 \mathrm{mg} / \mathrm{L}$ [37-39]. The performance of aerobic SOB as related to the available DO might be common to all bioreactor systems. However, bioreactors might differ from each other in the operational conditions to attain such low DO concentrations. It might be easy to control oxygen limited condition in an airlift bioreactor fed with liquid sulfide solutions by controlling the air dose to the bioreactor medium. On the other hand, in an airlift bioreactor fed with $\mathrm{H}_{2} \mathrm{~S}$-air mixture the $\mathrm{DO}$ concentration 
TABLE 1: Comparison between the maximum elimination capacity of the current airlift bioreactor and other studies.

\begin{tabular}{|c|c|c|c|}
\hline Type of bioreactor & Sulfide feed form & Maximum EC & Reference \\
\hline Biofilter packed with sodium alginate beads & $\mathrm{H}_{2} \mathrm{~S}$ gas & $8 \mathrm{~g} \mathrm{H}_{2} \mathrm{~S} \mathrm{~m}^{-3} \mathrm{~h}^{-1}$ & [3] \\
\hline Fixed film bioscrubber & $\mathrm{H}_{2} \mathrm{~S}$ gas & $19.4 \mathrm{~g} \mathrm{H}_{2} \mathrm{~S} \mathrm{~m}^{-3} \mathrm{~h}^{-1}$ & [5] \\
\hline Biofilter packed with organic materials & $\mathrm{H}_{2} \mathrm{~S}$ gas & $79 \mathrm{~g} \mathrm{H}_{2} \mathrm{~S} \mathrm{~m}^{-3} \mathrm{~h}^{-1}$ & [6] \\
\hline Biotrickling filter packed with polyurethane foam & $\mathrm{H}_{2} \mathrm{~S}$ gas & $55 \mathrm{~g} \mathrm{~S} \mathrm{~m}^{-3} \mathrm{~h}^{-1}$ & [2] \\
\hline Biofilter packed with GAC & $\mathrm{H}_{2} \mathrm{~S}$ gas & $125 \mathrm{~g} \mathrm{H}_{2} \mathrm{~S} \mathrm{~m}^{-3} \mathrm{~h}^{-1}$ & {$[25]$} \\
\hline Biotrickling filter packed with polyurethane foam & $\mathrm{H}_{2} \mathrm{~S}$ gas & $170 \mathrm{~g} \mathrm{~S} \mathrm{~m}^{-3} \mathrm{~h}^{-1}$ & {$[26]$} \\
\hline Industrial scale biotrickling filter packed with polypropylene Pall rings & $\mathrm{H}_{2} \mathrm{~S}$ gas & $110 \mathrm{~g} \mathrm{H}_{2} \mathrm{~S} \mathrm{~m}^{-3} \mathrm{~h}^{-1}$ & [27] \\
\hline Airlift bioreactor & Sulfide solution & $\begin{array}{l}4.3 \mathrm{~kg} \mathrm{~S} / \mathrm{kg} \text { VSS } \cdot \mathrm{d} \\
\left(\approx 160 \mathrm{~g} \mathrm{~S} \mathrm{~m}^{-3} \mathrm{~h}^{-1}\right)\end{array}$ & [29] \\
\hline Airlift bioreactor & Sulfide solution & $\begin{array}{c}6.7 \mathrm{~mol} / \mathrm{m}^{3} \cdot \mathrm{h} \\
\left(214.4 \mathrm{~g} \mathrm{~S} \mathrm{~m}^{-3} \mathrm{~h}^{-1}\right)\end{array}$ & {$[35]$} \\
\hline Airlift bioreactor & $\mathrm{H}_{2} \mathrm{~S}$ gas & $113 \mathrm{~g} \mathrm{H}_{2} \mathrm{~S} \mathrm{~m}^{-3} \mathrm{~h}^{-1}$ & This study \\
\hline
\end{tabular}

depends on many factors, of which $\mathrm{O}_{2} / \mathrm{H}_{2} \mathrm{~S}$ molar ratio in the feed gas stream and mass-transfer are important. Therefore, it was important to study the relationship between $\mathrm{O}_{2} / \mathrm{H}_{2} \mathrm{~S}$ molar ratio and the bioreactor performance in terms of $\%$ sulfur recovery and DO, which is specific for each airlift bioreactor.

The effect of $\mathrm{O}_{2} / \mathrm{H}_{2} \mathrm{~S}$ molar ratio on \% sulfur recovery is shown in Figure 4(b). Sulfur recovery increased at lower $\mathrm{O}_{2} / \mathrm{H}_{2} \mathrm{~S}$ molar ratios. Higher than $90 \%$ conversion to elemental sulfur was achieved at $\mathrm{O}_{2} / \mathrm{H}_{2} \mathrm{~S}$ molar ratios lower than 10 . On the other hand, sulfate was the dominant end product at $\mathrm{O}_{2} / \mathrm{H}_{2} \mathrm{~S}$ molar ratios $>20$.

Compared to other bioreactors, the $\mathrm{O}_{2} / \mathrm{H}_{2} \mathrm{~S}$ molar ratio that achieved maximum sulfur recovery in this study was found to be higher. In two of the other bioreactors $[1,28]$ packing material (e.g., polyurethane foam and polypropylene grid) was used to enhance mass-transfer of both $\mathrm{H}_{2} \mathrm{~S}$ and oxygen. However, these types of packing materials may suffer from clogging by sulfur particles. In another bioreactor [30] sulfide solution and air were mixed in a separate stirred vessel, which might add to the operating cost of the bioreactor.

This comparison indicates that oxygen availability in the cell suspension is a function of mass-transfer. Figure 5 shows the relationship between the inlet $\mathrm{O}_{2} / \mathrm{H}_{2} \mathrm{~S}$ molar ratio and dissolved oxygen, which is a characteristic of the current airlift bioreactor. An improvement in mass-transfer is expected to increase the slope of the linear equation.

The maximum conversion of $\mathrm{H}_{2} \mathrm{~S}$ into elemental sulfur achieved in the airlift bioreactor with the current configuration was $95 \%$, which is comparable to that achieved in some studies $[1,40]$ while being much higher than in others $[29,41]$.

During the last three months of the bioreactor operation the average percentage of $\mathrm{H}_{2} \mathrm{~S}$ converted into thiosulfate was $0.67 \pm 0.11 \%$, mainly due to auto-oxidation of sulfide $[30,41]$ and/or reaction of sulfur with $\mathrm{OH}^{-}$ion in alkaline solution $[34,42,43]$. The highest conversion to thiosulfate was obtained at higher $\mathrm{O}_{2} / \mathrm{H}_{2} \mathrm{~S}$ molar ratios. Additionally, an average of $2.1 \%$ of the inlet sulfide was detected as sulfide in the outlet solution, which is very close to that reported by Fortuny et al. [1].

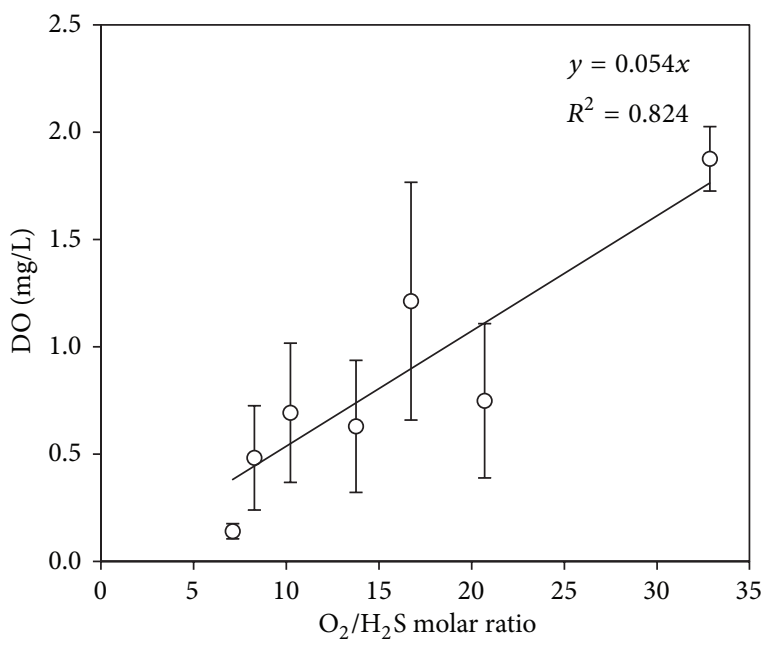

FIGURE 5: Correlation between $\mathrm{O}_{2} / \mathrm{H}_{2} \mathrm{~S}$ molar ratio and DO.

3.3. The Effect of $p H$ on Bioconversion End Product. The effect of $\mathrm{pH}$ on sulfur recovery was observed under oxygenlimited conditions (Figure 6(a)) and under excess oxygen (Figure 6(b)). At oxygen-limited conditions there was a slight increase of $\%$ sulfur recovery as the $\mathrm{pH}$ was increased. On the other hand, a decreased \% sulfur recovery was observed at higher $\mathrm{pH}$ when oxygen was in excess.

It was found in previous studies that sulfur reacts with $\mathrm{OH}^{-}$ion in alkaline solution according to the following equation [34]:

$$
(4+2 x) \mathrm{S}+6 \mathrm{OH}^{-} \longrightarrow 2 \mathrm{~S}_{x+1}{ }^{2-}+\mathrm{S}_{2} \mathrm{O}_{3}{ }^{2-}+3 \mathrm{H}_{2} \mathrm{O} .
$$

In the presence of excess sulfur (i.e., $x>0$ ), which is the case at oxygen-limited conditions, polysulfide forms [42]. In this study polysulfide was included in elemental sulfur concentration since $S^{\circ}$ concentration was calculated by mass balance, taking into account the inlet sulfide and the outlet sulfide, sulfate, and thiosulfate. This might explain the increasing trend of sulfur recovery with $\mathrm{pH}$ at oxygen-limited 


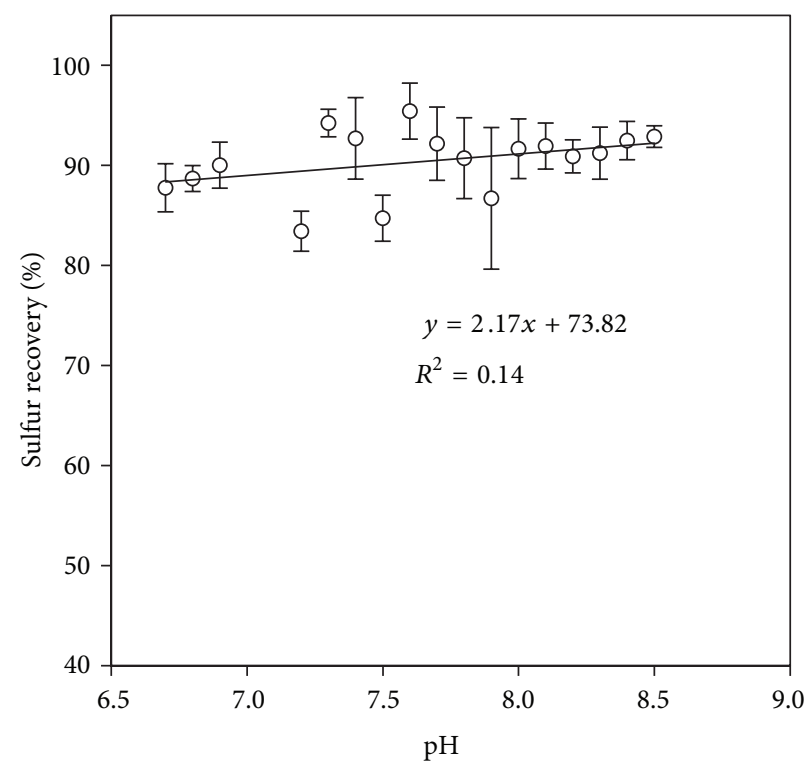

(a)

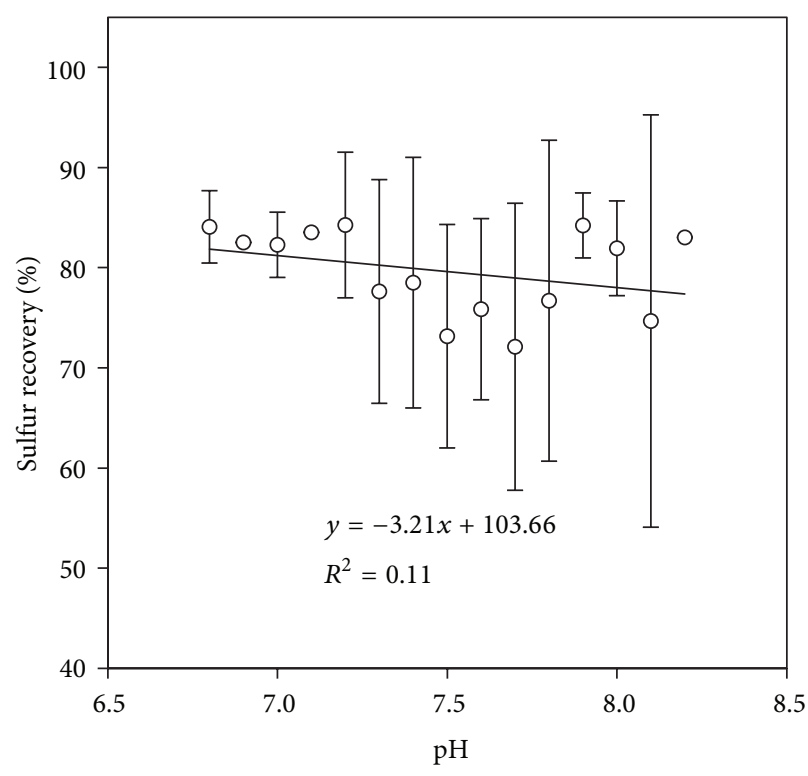

(b)

Figure 6: Effect of $\mathrm{pH}$ on bioconversion end product: (a) $\mathrm{O}_{2} / \mathrm{H}_{2} \mathrm{~S}$ molar ratio $<10$ and (b) $\mathrm{O}_{2} / \mathrm{H}_{2} \mathrm{~S}$ molar ratio $10-20$.

conditions (Figure 6(a)). On the other hand, at excessive oxygen conditions the produced elemental sulfur in the bioreactor was less. According to (4), less sulfur might result in sulfide formation on the expense of elemental sulfur. This might explain the decrease of sulfur recovery at high $\mathrm{pH}$ and excess oxygen (Figure 6(b)).

3.4. Effect of Accumulated Sulfide Concentration on Bioconversion Efficiency. The performance of the bioreactor in terms of $\mathrm{H}_{2} \mathrm{~S}$ removal efficiency at four $\mathrm{pH}$ ranges and various accumulated sulfide concentrations is illustrated in Figure 7. The removal efficiency sharply dropped below $90 \%$ when the total accumulated sulfide concentration exceeded about 100 and $150 \mathrm{mg} / \mathrm{L}$ at $\mathrm{pH}$ ranges 6.5-6.9 and 7.0-7.4, respectively. The bioreactor performance severely dropped at higher accumulated sulfide concentrations. On the other hand, much higher concentrations of accumulated sulfide were tolerated at higher $\mathrm{pH}$ ranges. For instance, the removal efficiency was slightly affected under accumulated sulfide concentrations higher than $320 \mathrm{mg} / \mathrm{L}$ at $\mathrm{pH}$ range 7.5-7.9, however, remaining higher than $97 \%$. At $\mathrm{pH}$ range of $8.0-8.5$ the removal efficiency was not affected even at accumulated sulfide concentrations up to about $500 \mathrm{mg} / \mathrm{L}$. Higher concentrations were not studied.

The combined effect of both accumulated sulfide and $\mathrm{pH}$ might be explained by three factors: (a) mass-transfer, (b) biological activity, and (c) the presence of unionized sulfide. $\mathrm{H}_{2} \mathrm{~S}$ is an acidic gas that is expected to be absorbed in the bioreactor solution more easily at high $\mathrm{pH}$ values. Unless the resident SOB is capable of consuming the absorbed $\mathrm{H}_{2} \mathrm{~S}$ gas dissolved sulfide will accumulate up to levels that are harmful to the resident microorganisms. Sulfide is toxic at higher concentrations for many bacteria. The inhibitory effect of sulfides presumed to be caused by unionized $\mathrm{H}_{2} \mathrm{~S}$ because only neutral molecules can permeate well through the cell membrane [44].

The fraction of unionized $\mathrm{H}_{2} \mathrm{~S}$ of the total sulfide is very much dependent on $\mathrm{pH}$. Hydrogen sulfide is a diprotic acid that dissociate in two steps:

$$
\begin{aligned}
& \mathrm{H}_{2} \mathrm{~S} \longleftrightarrow \mathrm{H}^{+}+\mathrm{HS}^{-} \\
& K_{1}=\frac{\left[\mathrm{H}^{+}\right]\left[\mathrm{HS}^{-}\right]}{\left[\mathrm{H}_{2} \mathrm{~S}\right]}=10^{-7} \mathrm{Mol} \mathrm{L}^{-1} \text { at } 20^{\circ} \mathrm{C} \\
& \mathrm{HS}^{-} \longleftrightarrow \mathrm{H}^{+}+\mathrm{S}^{-2} \\
& K_{2}=\frac{\left[\mathrm{H}^{+}\right]\left[\mathrm{S}^{-2}\right]}{\left[\mathrm{HS}^{-}\right]}=0.8 \times 10^{-17} \mathrm{Mol} \mathrm{L}^{-1} \text { at } 20^{\circ} \mathrm{C} .
\end{aligned}
$$

Since the dissociation constant $K_{2}$ is always so low (other values are reported), the equilibrium with $\mathrm{S}^{-2}$ can be neglected at intermediate $\mathrm{pH}$ values [45]. Therefore, at neutral to slightly alkaline conditions, only the equilibrium between $\mathrm{H}_{2} \mathrm{~S}$ and $\mathrm{HS}^{-}$is considered.

$K_{1}$ is the dissociation constant. Its value changes with temperature $\left(T^{\circ} \mathrm{K}\right)$ according to [33]:

$$
\begin{gathered}
p K_{1}=32.55+\frac{1519.44}{T}-15.672 \log _{10} T+0.02722 T \\
p K_{1}=-\log _{10} K_{1} .
\end{gathered}
$$

The unionized $\mathrm{H}_{2} \mathrm{~S}$ fraction of the total dissolved sulfide ( $f$ ) can be calculated using $K_{1}$ and $\mathrm{pH}$ values according to the following equation [46]:

$$
f=\left(1+\frac{K_{1}}{10^{-\mathrm{pH}}}\right)^{-1} \text {. }
$$




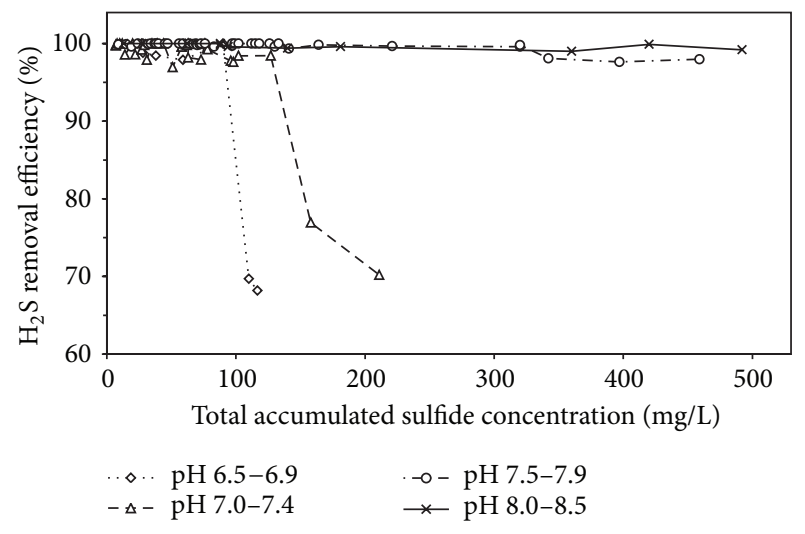

FIGURE 7: Effect of accumulated sulfide on bioconversion efficiency at various $\mathrm{pH}$ ranges.

The accumulated sulfide concentrations $100 \mathrm{mg} / \mathrm{L}$ (at pH range 6.5-6.9, average 6.7) and $150 \mathrm{mg} / \mathrm{L}$ (at $\mathrm{pH}$ range 7.07.4, average 7.2) beyond which inhibition of the SOB started (Figure 7) correspond to unionized $\mathrm{H}_{2} \mathrm{~S}$ fractions of 0.63 and 0.35 , respectively. These are equivalent to unionized sulfide concentrations of 63 and $52.5 \mathrm{mg} / \mathrm{L}$, respectively. The $50 \%$ inhibitive unionized sulfide concentration was not studied but is expected to be higher than these two concentrations. Considering the least unionized sulfide concentration $(52.5 \mathrm{mg} / \mathrm{L})$, the equivalent total sulfide that can be tolerated by the SOB at $\mathrm{pH}$ ranges 7.5-7.9 (average: 7.7) and 8.08.5 (average 8.2 ) is expected to be 375 and $1050 \mathrm{mg} / \mathrm{L}$, respectively.

Using Henry's law at $30^{\circ} \mathrm{C}$ (partition coefficient is about 2.0 ), the gas phase concentration of $\mathrm{H}_{2} \mathrm{~S}$ that can be tolerated without inhibition of the resident SOB can be calculated as about $38000,57000,142000$, and $396000 \mathrm{ppm}$ at $\mathrm{pH}$ values of $6.7,7.2,7.7$, and 8.2, respectively, assuming optimum masstransfer rate and the presence of sufficient microorganisms to consume the absorbed $\mathrm{H}_{2} \mathrm{~S}$.

\section{Conclusion}

A maximum $\mathrm{H}_{2} \mathrm{~S}$ elimination capacity of $113 \mathrm{~g} \mathrm{H}_{2} \mathrm{~S} \mathrm{~m}^{-3} \mathrm{~h}^{-1}$ was achieved in the airlift bioreactor under investigation at loading rates up to $130 \mathrm{~g} \mathrm{H}_{2} \mathrm{~S} \mathrm{~m}^{-3} \mathrm{~h}^{-1}$, a result indicating the feasibility of using such bioreactor in biotreatment of high concentrations of $\mathrm{H}_{2} \mathrm{~S}$ in air streams directly injected into the bioreactor.

$\mathrm{pH}$ is an important parameter that should be adjusted for better performance of the bioreactor. The effect of $\mathrm{pH}$ in association with other factors on the bioreactor performance was studied. It was found that the current airlift bioreactor (with the resident $\mathrm{SOB}$ ) was capable of achieving almost the same $\mathrm{H}_{2} \mathrm{~S}$ elimination capacity at a wide range of $\mathrm{pH}$, particularly 7-8.5. At lower $\mathrm{pH}$ values, the elimination capacity was lower.

The bioreactor achieved maximum elemental sulfur recovery (about 95\%) under oxygen limited conditions (DO below $0.2 \mathrm{mg} / \mathrm{L}$ ). At low DO levels, higher $\mathrm{pH}$ values increased elemental sulfur recovery.
The resident SOB in the bioreactor tolerated accumulated sulfide concentrations higher than $500 \mathrm{mg} / \mathrm{L}$ at higher $\mathrm{pH}$ values (8.0-8.5) and near 100\% removal efficiency was achieved. However, lower $\mathrm{pH}$ reduced the maximum tolerated accumulated sulfide in cell suspension.

The overall conclusion is, therefore, that the resident $\mathrm{SOB}$ in the studied airlift bioreactor favored $\mathrm{pH}$ values in the slightly alkaline range. The bioreactor performance in terms of elimination capacity and sulfur recovery was better at the alkaline $\mathrm{pH}$ range $8-8.5$. The ability of the airlift bioreactor used in this study to handle the high inlet concentrations of $\mathrm{H}_{2} \mathrm{~S}$ is a proof that it can be a promising option for treatment of gas streams such as biogas from anaerobic digesters or landfills which may contain $\mathrm{H}_{2} \mathrm{~S}$ concentrations up to several thousand ppm. However, more studies are recommended to apply gas streams with composition similar to that emitted from such processes.

\section{Conflict of Interests}

The authors declare that there is no conflict of interests regarding the publication of this paper.

\section{Acknowledgments}

This project was funded by the Ministry of Higher Education (MOHE), Saudi Arabia under Grant no. (1/A/3). The authors would like to thank MOHE and King Abdulaziz University, Deanship of Scientific Research, for technical and financial support.

\section{References}

[1] M. Fortuny, J. A. Baeza, X. Gamisans et al., "Biological sweetening of energy gases mimics in biotrickling filters," Chemosphere, vol. 71, no. 1, pp. 10-17, 2008.

[2] M. Ramírez, J. M. Gómez, G. Aroca, and D. Cantero, "Removal of hydrogen sulfide by immobilized Thiobacillus thioparus in a biotrickling filter packed with polyurethane foam," Bioresource Technology, vol. 100, no. 21, pp. 4989-4995, 2009.

[3] J. H. Kim, E. R. Rene, and H. S. Park, "Biological oxidation of hydrogen sulfide under steady and transient state conditions in an immobilized cell biofilter," Bioresource Technology, vol. 99, no. 3, pp. 583-588, 2008.

[4] P. Oyarzún, F. Arancibia, C. Canales, and G. E. Aroca, "Biofiltration of high concentration of hydrogen sulphide using Thiobacillus thioparus," Process Biochemistry, vol. 39, no. 2, pp. 165-170, 2003.

[5] S. Potivichayanon, P. Pokethitiyook, and M. Kruatrachue, "Hydrogen sulfide removal by a novel fixed-film bioscrubber system," Process Biochemistry, vol. 41, no. 3, pp. 708-715, 2006.

[6] J. L. R. P. Filho, L. T. Sader, M. H. R. Z. Damianovic, E. Foresti, and E. L. Silva, "Performance evaluation of packing materials in the removal of hydrogen sulphide in gas-phase biofilters: polyurethane foam, sugarcane bagasse, and coconut fibre," Chemical Engineering Journal, vol. 158, no. 3, pp. 441-450, 2010.

[7] D. Park, D. S. Lee, J. Y. Joung, and J. M. Park, "Comparison of different bioreactor systems for indirect $\mathrm{H}_{2} \mathrm{~S}$ removal using 
iron-oxidizing bacteria," Process Biochemistry, vol. 40, no. 3-4, pp. 1461-1467, 2005.

[8] Y. C. Chung, C. Huang, and C.-P. Tseng, "Microbial oxidation of hydrogen sulfide with biofilter," Journal of Environmental Science and Health, vol. 31, no. 6, pp. 1263-1278, 1996.

[9] Y. Yang and E. R. Allen, "Biofiltration control of hydrogen sulfide: 1. Design and operational parameters," Journal of the Air \& Waste Management Association, vol. 44, no. 7, pp. 863-868, 1994.

[10] A. H. Wani, A. K. Lau, and R. M. R. Barnion, "Biofiltration control of pulping odors- hydrogen sulfide: performance, macrokinetics and coexistence effects of organo-sulfur species," Journal of Chemical Technology and Biotechnology, vol. 74, pp. 9-16, 1999.

[11] Y. Yang and E. R. Allen, "Biofiltration control of hydrogen sulfide: 2 . Kinetics, biofilter performance, and maintenance," Journal of the Air and Waste Management Association, vol. 44, no. 11, pp. 1315-1321, 1994.

[12] K. Kim, W. Chung, and Y. Oh, "Dynamic behavior of compost biofilters during periods of starvation and fluctuating hydrogen sulfide loadings," Journal of Environmental Science and Health, vol. 39, no. 1, pp. 299-307, 2004.

[13] Y. C. Chung and C. Huang, "Removal of hydrogen sulphide by immobilized Thiobacillus sp. strain CH11 in a biofilter," Journal of Chemical Technology and Biotechnology, vol. 69, no. 1, pp. 5862, 1997.

[14] D. Gabriel and M. A. Deshusses, "Performance of a full-scale biotrickling filter treating $\mathrm{H}_{2} \mathrm{~S}$ at a gas contact time of 1.6 to 2.2 seconds," Environmental Progress, vol. 22, no. 2, pp. 111-118, 2003.

[15] S. Kim and M. A. Deshusses, "Development and experimental validation of a conceptual model for biotrickling filtration of $\mathrm{H}_{2}$ S," Environmental Progress, vol. 22, no. 2, pp. 119-128, 2003.

[16] D. H. Park, J. M. Cha, H. W. Ryu et al., "Hydrogen sulfide removal utilizing immobilized Thiobacillus sp. IW with Caalginate bead," Biochemical Engineering Journal, vol. 11, no. 2-3, pp. 167-173, 2002.

[17] K. Shinabe, S. Oketani, T. Ochi, S. Kanchanatawee, and M. Matsumura, "Characteristics of hydrogen sulfide removal in a carrier-packed biological deodorization system," Biochemical Engineering Journal, vol. 5, no. 3, pp. 209-217, 2000.

[18] H. Duan, R. Yan, L. C. C. Koe, and X. Wang, "Combined effect of adsorption and biodegradation of biological activated carbon on $\mathrm{H}_{2} \mathrm{~S}$ biotrickling filtration," Chemosphere, vol. 66, no. 9, pp. 1684-1691, 2007.

[19] H. Duan, L. C. C. Koe, R. Yan, and X. Chen, "Biological treatment of $\mathrm{H}_{2} \mathrm{~S}$ using pellet activated carbon as a carrier of microorganisms in a biofilter," Water Research, vol. 40, no. 14, pp. 2629-2636, 2006.

[20] K. Cho, M. Hirai, and M. Shoda, "Degradation of hydrogen sulfide by Xanthomonas sp. strain DY44 isolated from peat," Applied and Environmental Microbiology, vol. 58, no. 4, pp. 11831189, 1992.

[21] H. S. J. Yoshizawa and S. Kametani, "Bacteria help desulfurize gas," Hydrocarbon Processing, vol. 67, pp. 76D-76F, 1988.

[22] S. Ebrahimi, F. J. F. Morales, R. Kleerebezem, J. J. Heijnen, and M. C. M. van Loosdrecht, "High-rate acidophilic ferrous iron oxidation in a biofilm airlift reactor and the role of the carrier material," Biotechnology and Bioengineering, vol. 90, no. 4, pp. 462-472, 2005.
[23] H. Son and J. Lee, " $\mathrm{H}_{2} \mathrm{~S}$ removal with an immobilized cell hybrid reactor," Process Biochemistry, vol. 40, no. 6, pp. 2197-2203, 2005.

[24] C. Pagella and D. M. De Faveri, " $\mathrm{H}_{2} \mathrm{~S}$ gas treatment by iron bioprocess," Chemical Engineering Science, vol. 55, no. 12, pp. 2185-2194, 2000.

[25] C. Rattanapan, P. Boonsawang, and D. Kantachote, "Removal of $\mathrm{H}_{2} \mathrm{~S}$ in down-flow GAC biofiltration using sulfide oxidizing bacteria from concentrated latex wastewater," Bioresource Technology, vol. 100, no. 1, pp. 125-130, 2009.

[26] M. Fernández, M. Ramírez, J. M. Gómez, and D. Cantero, "Biogas biodesulfurization in an anoxic biotrickling filter packed with open-pore polyurethane foam," Journal of Hazardous Materials, vol. 264, pp. 529-535, 2014.

[27] G. Rodriguez, A. D. Dorado, M. Fortuny, D. Gabriel, and X. Gamisans, "Biotrickling filters for biogas sweetening: oxygen transfer improvement for a reliable operation," Process Safety and Environmental Protection, vol. 92, no. 3, pp. 261-268, 2014.

[28] C. J. N. Buisman, B. G. Geraats, P. IJspeert, and G. Lettinga, "Optimization of sulphur production in a biotechnological sulphide-removing reactor," Biotechnology and Bioengineering, vol. 35, no. 1, pp. 50-56, 1990.

[29] J. Lohwacharin and A. P. Annachhatre, "Biological sulfide oxidation in an airlift bioreactor," Bioresource Technology, vol. 101, no. 7, pp. 2114-2120, 2010.

[30] A. J. H. Janssen, S. C. Ma, P. Lens, and G. Lettinga, "Performance of a sulfide-oxidizing expanded-bed reactor supplied with dissolved oxygen," Biotechnology and Bioengineering, vol. 53, pp. 32-40, 1997.

[31] A. J. H. Janssen, G. Lettinga, and A. de Keizer, "Removal of hydrogen sulphide from wastewater and waste gases by biological conversion to elemental sulphur: colloidal and interfacial aspects of biologically produced sulphur particles," Colloids and Surfaces A: Physicochemical and Engineering Aspects, vol. 151, no. 1-2, pp. 389-397, 1999.

[32] B. Krishnakumar, S. Majumdar, V. B. Manilal, and A. Haridas, "Treatment of sulphide containing wastewater with sulphur recovery in a novel reverse fluidized loop reactor (RFLR)," Water Research, vol. 39, no. 4, pp. 639-647, 2005.

[33] American Public Health Association (APHA), Standard Methods for the Examination of Water \& Wastewater, APHA, Washington, DC, USA, 21st edition, 2005.

[34] H. Satake, T. Hisano, and S. Ikeda, "The rapid determination of sulfide, thiosulfate, and polysulfide in the lixiviation water of blast-furnace slag by means of argentometric potentiometric titration," Bulletin of the Chemical Society of Japan, vol. 54, pp. 1968-1971, 1981.

[35] G. M. M. Moghanloo, E. Fatehifar, S. Saedy, Z. Aghaeifa, and H. Abbasnezhad, "Biological oxidation of hydrogen sulfide in mineral media using a biofilm airlift suspension reactor," Bioresource Technology, vol. 101, no. 21, pp. 8330-8335, 2010.

[36] P. F. Henshaw and W. Zhu, "Biological conversion of hydrogen sulphide to elemental sulphur in a fixed-film continuous flow photo-reactor," Water Research, vol. 35, no. 15, pp. 3605-3610, 2001.

[37] C. Vannini, G. Munz, G. Mori, C. Lubello, F. Verni, and G. Petroni, "Sulphide oxidation to elemental sulphur in a membrane bioreactor: performance and characterization of the selected microbial sulphur-oxidizing community," Systematic and Applied Microbiology, vol. 31, no. 6-8, pp. 461-473, 2008.

[38] A. J. H. Janssen, S. Meijer, J. Botsema, and G. Lettinga, "Application of the redox potential for controlling a sulfide 
oxidating bioreactor," Biotechnology and Bioengineering, vol. 60, pp. 147-155, 1998.

[39] A. D. Levine, B. J. Raymer, and J. Jahn, "Evaluation of biological hydrogen sulfide oxidation coupled with two-stage upflow filtration for groundwater treatment," Journal of Environmental Science and Health A, vol. 39, no. 5, pp. 1263-1279, 2004.

[40] P. F. Henshaw, J. K. Bewtra, and N. Biswas, "Hydrogen sulphide conversion to elemental sulphur in a suspended-growth continuous stirred tank reactor using Chlorobium limicola," Water Research, vol. 32, no. 6, pp. 1769-1778, 1998.

[41] A. J. H. Janssen, R. Sleyster, C. van der Kaa, A. Jochemsen, J. Bontsema, and G. Lettinga, "Biological sulphide oxidation in a fed-batch reactor," Biotechnology and Bioengineering, vol. 47, no. 3, pp. 327-333, 1995.

[42] R. H. Arnston, F. W. Dickson, and G. Tunell, "Systems S- $\mathrm{Na}_{2} \mathrm{O}-$ $\mathrm{H}_{2} \mathrm{O}$ and $\mathrm{S}-\mathrm{H}_{2} \mathrm{O}$ : application to the mode of origin of natural alkaline polysulfide and thiosulfate solutions," American Journal of Science, vol. 8, pp. 574-582, 1960.

[43] S. A. Khan, "UV-ATR spectroscopy study of the speciation in aqueous polysulfide electrolyte solutions," International Journal of Electrochemical Science, vol. 7, no. 1, pp. 561-568, 2012.

[44] L. W. H. Pol, P. N. L. Lens, A. J. M. Stams, and G. Lettinga, "Anaerobic treatment of sulphate-rich wastewaters," Biodegradation, vol. 9, no. 3-4, pp. 213-224, 1998.

[45] W. E. Kleinjan, A. de Keizer, and A. J. H. Janssen, "Equilibrium of the reaction between dissolved sodium sulfide and biologically produced sulfur," Colloids and Surfaces B: Biointerfaces, vol. 43, no. 3-4, pp. 228-237, 2005.

[46] Z. Isa, S. Grusenmeyer, and W. Vestraete, "Sulfate reduction relative to methane production in high-rate anaerobic digestion: technical aspects," Applied and Environmental Microbiology, vol. 51, no. 3, pp. 572-579, 1986. 

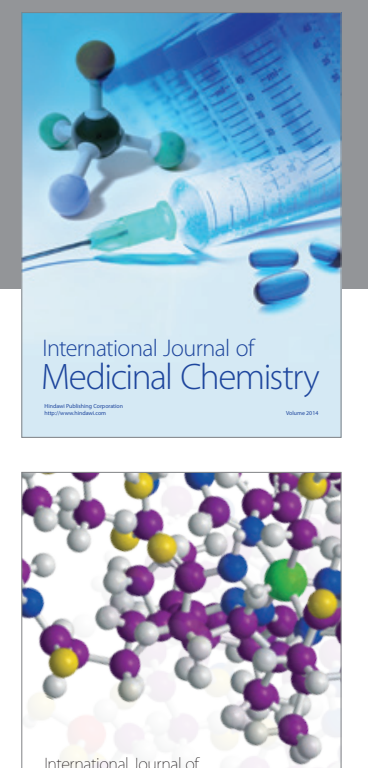

\section{Carbohydrate} Chemistry

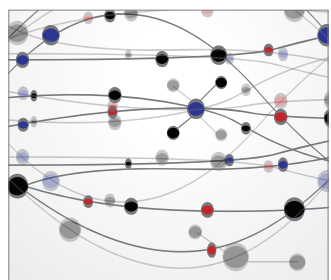

The Scientific World Journal
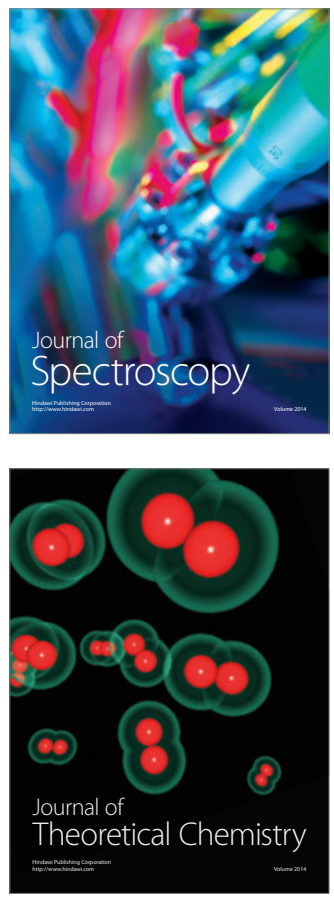
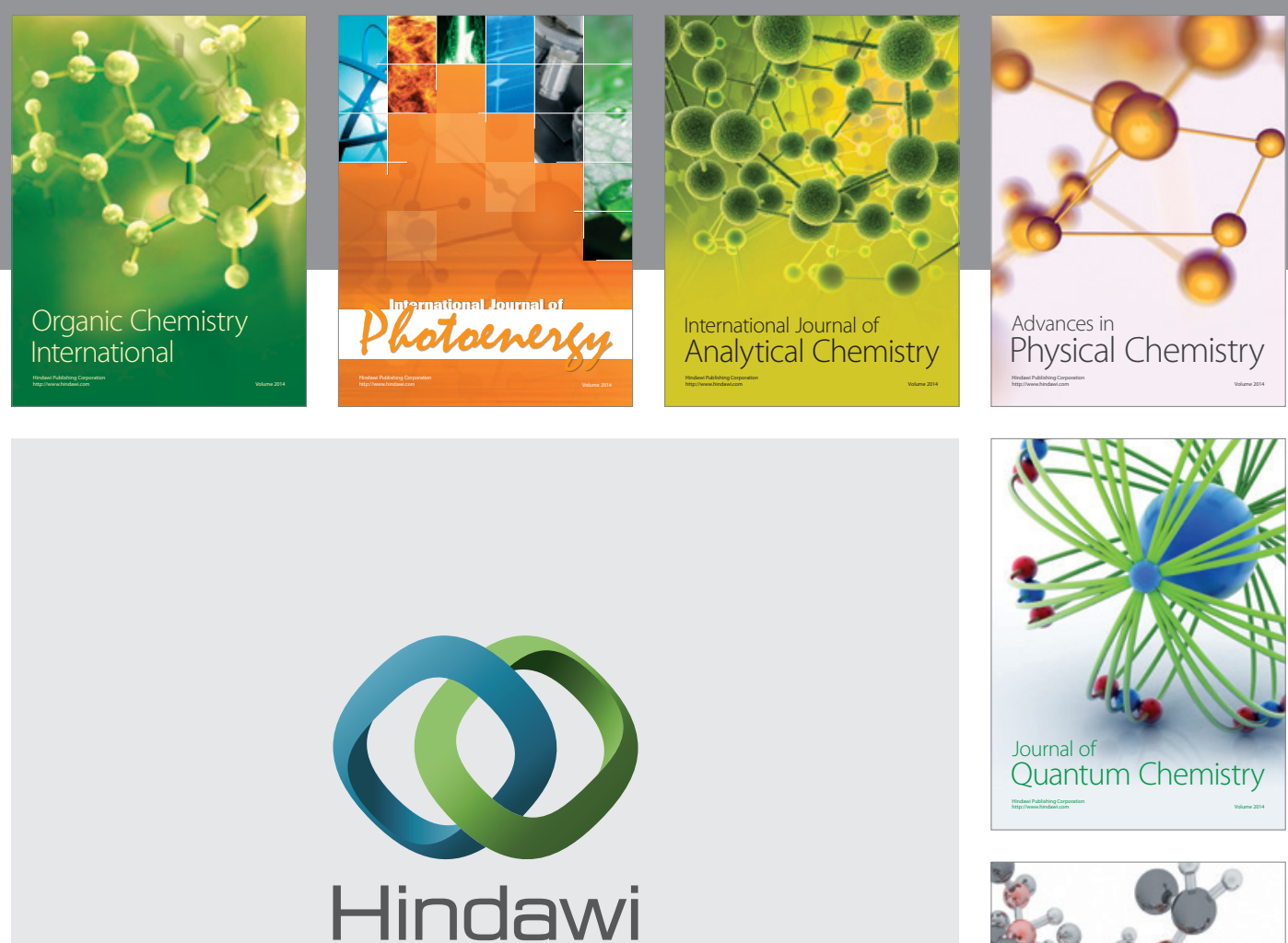

Submit your manuscripts at

http://www.hindawi.com

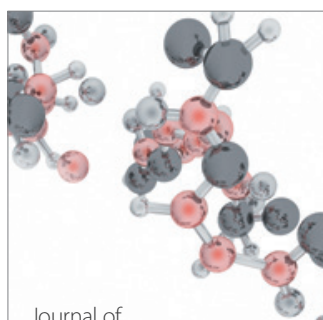

Analytical Methods

in Chemistry

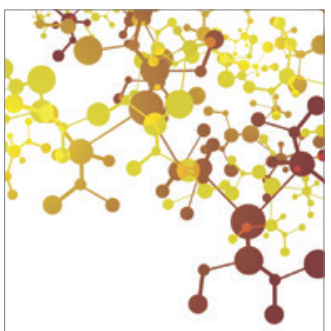

Journal of

Applied Chemistry

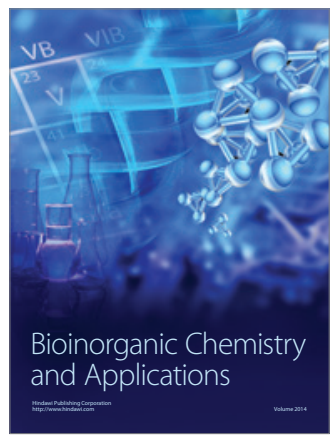

Inorganic Chemistry
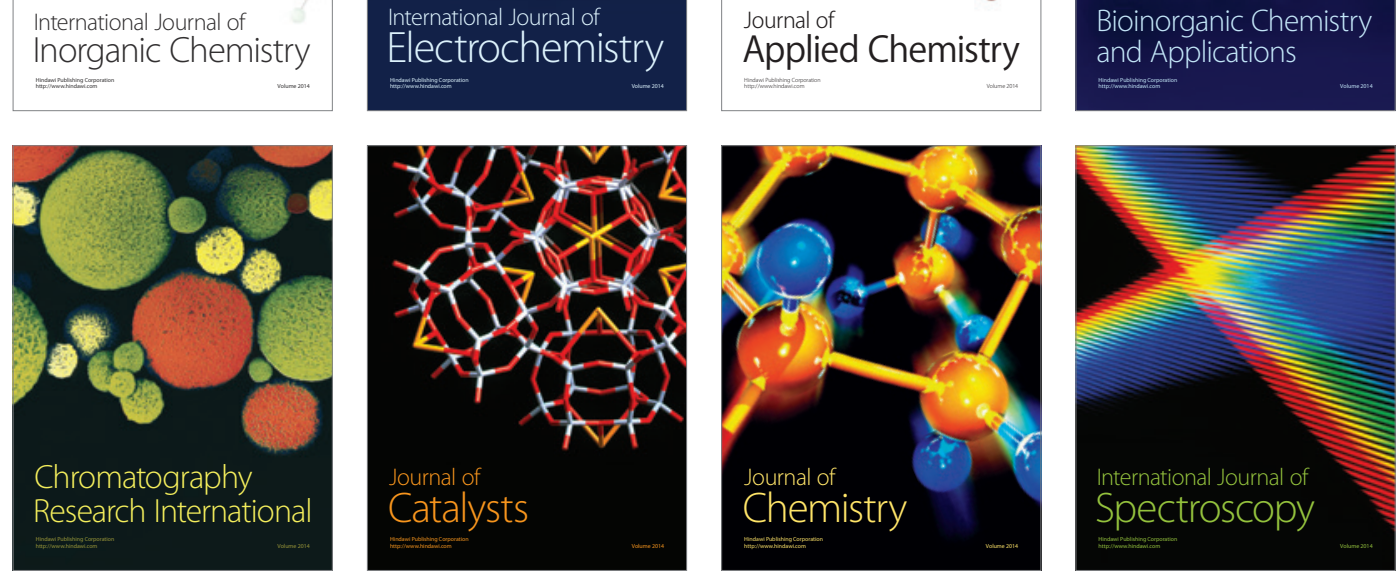